\title{
Activated carbon-supported ruthenium as an efficient catalyst for selective aerobic oxidation of 5-hydroxymethylfurfural to 2,5-diformylfuran
}

\author{
NIE Junfang, XIE Jiahan, LIU Haichao* \\ Beijing National Laboratory for Molecular Sciences, State Key Laboratory for Structural Chemistry of Stable and Unstable Species, \\ College of Chemistry and Molecular Engineering, Peking University, Beijing 100871, China
}

A R T I C L E I N F O

Article history:

Received 6 January 2013

Accepted 18 February 2013

Published 20 May 2013

\section{Keywords:}

Biomass

5-Hydroxymethylfurfural

2,5-Diformylfuran

Aerobic oxidation

Ruthenium catalyst

\begin{abstract}
A B S T R A C T
The aerobic oxidation of 5-hydroxymethylfurfural (HMF) to 2,5-diformylfuran (DFF) was performed on an activated carbon-supported ruthenium $(\mathrm{Ru} / \mathrm{C})$ catalyst. The excellent DFF yield of 95.8\% was achieved at $383 \mathrm{~K}$ and $\mathrm{O}_{2}$ pressure $2.0 \mathrm{MPa}$ in toluene. It exhibited superior activity and DFF selectivity than other C-supported noble metals (i.e. Pt, $\mathrm{Rh}, \mathrm{Pd}$, and $\mathrm{Au}$ ) with comparable nanoparticle size. The $\mathrm{Ru} / \mathrm{C}$ catalyst was stable and can be recycled by a simple hydrothermal treatment. Moreover, the product distribution in the HMF oxidation on $\mathrm{Ru} / \mathrm{C}$ can be tuned by the use of water as solvent and the addition of hydrotalcite, giving either 5-formyl-2-furancarboxylic acid or 2,5-furandicarboxylic acid as the dominant product.
\end{abstract}

(C) 2013, Dalian Institute of Chemical Physics, Chinese Academy of Sciences. Published by Elsevier B.V. All rights reserved.
Because of increasing attention to the use of biomass [1,2], 5-hydroxymethylfurfural (HMF) has been identified as one of the important biomass-based platform molecules for the sustainable production of chemicals and fuels $[3,4]$. HMF can be converted to a variety of useful chemicals, and one such example is 2,5-diformylfuran (DFF). Similar to HMF, DFF is a versatile intermediate and is used in the synthesis of fungicides, pharmaceuticals, and functional polymers with numerous applications [5-8].

Selective aerobic oxidation of HMF forms DFF, but the presence of the more reactive aldehyde group in HMF makes it difficult to get high yields of DFF from this reaction. To improve this selectivity, a number of homogeneous and heterogeneous catalysts have been explored to date [9-17]. Moreau et al. [9] reported that HMF was converted to DFF with $93 \%$ selectivity and $91 \%$ conversion on $\mathrm{V}_{2} \mathrm{O}_{5} / \mathrm{TiO}_{2}$ with a high weight ratio of catalyst to HMF (i.e. 2:1 by weight), reflecting the low catalytic activity. By using homogeneous $\mathrm{VOSO}_{4} / \mathrm{Cu}\left(\mathrm{NO}_{3}\right)_{2}$ catalysts in acetonitrile, Ma et al. [10] obtained a nearly quantitative yield of DFF at $353 \mathrm{~K}$ but suffered from a difficult catalyst recovery. Takagaki et al. [14] achieved a 92\% yield of DFF with a hydrotalcite (HT)-supported $\mathrm{Ru}(\mathrm{OH})_{x}$ catalyst $\left(\mathrm{Ru}(\mathrm{OH})_{x} / \mathrm{HT}\right)$ in DMF. Antonyraj et al. [17] reported a $~ 97 \%$ DFF yield on $\mathrm{RuCl}_{3} / \mathrm{Al}_{2} \mathrm{O}_{3}$. However, the $\mathrm{Ru}(\mathrm{OH})_{x} / \mathrm{HT}$ and $\mathrm{RuCl}_{3} / \mathrm{Al}_{2} \mathrm{O}_{3}$ catalysts were deactivated significantly when recycled [14,17]. A similarly high DFF yield has also been reported recently by Yang et al. [15] with $\mathrm{MnO}_{2}$-based catalysts in dimethyl sulfoxide (DMSO). However, DMSO tends to undergo disproportionation to noxious and toxic $\mathrm{Me}_{2} \mathrm{SO}_{2}$ and $\mathrm{Me}_{2} \mathrm{~S}$ under oxidizing conditions [18,19]. Herein, we report that activated car-

\footnotetext{
* Corresponding author. Tel: +86-10-62754031; Fax: +86-10-62754031; E-mail: hcliu@pku.edu.cn This work was supported by the National Natural Science Foundation of China (20825310, 20973011, and 21173008) and the National Basic Research Program of China (973 Program, 2011CB808700 and 2011CB201400). 
bon-supported $\mathrm{Ru}(\mathrm{Ru} / \mathrm{C})$ acts as an efficient and recyclable heterogeneous catalyst for selective aerobic oxidation of HMF to DFF in toluene with yields as high as $\sim 96 \%$ under mild conditions.

$\mathrm{Ru} / \mathrm{C}$ was prepared by incipient wetness impregnation of activated carbon with an aqueous solution of $\mathrm{RuCl}_{3} \cdot n \mathrm{H}_{2} \mathrm{O}$, followed by evaporation and drying at $383 \mathrm{~K}$ in air overnight, and subsequent reduction in a flow of $20 \% \mathrm{H}_{2}$ in $\mathrm{N}_{2}$ at $623 \mathrm{~K}$ for $4 \mathrm{~h}$ [20]. Similarly, Pt/C, Pd/C, and Rh/C were prepared for comparison [20]. The metal loadings of these catalysts were $3 \mathrm{wt} \%$. In accordance with our previous report, $1 \mathrm{wt} \% \mathrm{Au} / \mathrm{C}$ was prepared by a single-step borohydride reduction [21]. HMF oxidation reactions were carried out in a Teflon-lined stainless steel autoclave (50 ml). Typically, $1 \mathrm{mmol}$ HMF (98\%) and $40 \mathrm{mg}$ catalyst were added to $10 \mathrm{ml}$ toluene in the autoclave. The reactants and products were analyzed by HPLC using a UV detector and an Alltech OA-1000 organic acid column [13]. HMF reaction activities were reported as molar HMF conversion rates per mole of dispersed metal per hour and selectivities on a carbon basis. The Ru contents in the catalysts and in the filtrate after the HMF oxidation reaction were measured by inductively coupled plasma-atomic emission spectroscopy (ICP-AES, Profile Spec, Leeman Labs). X-ray photoelectron spectra (XPS) of Ru $3 p$ were collected on an AXIS Ultra spectrometer (Kratos, Manchester, UK) using an $\mathrm{Al}$ anode ( $\mathrm{Al} K_{\alpha}, h v$ $=1486.6 \mathrm{eV}$ ) operating at $150 \mathrm{~W}$.

Figure 1 shows how the oxidation activities and selectivities to DFF and 5-formyl-2-furancarboxylic acid (FFCA) vary with the HMF conversions over $\mathrm{Ru} / \mathrm{C}$ at $383 \mathrm{~K}$ and $2.0 \mathrm{MPa} \mathrm{O}_{2}$. The DFF selectivity was essentially constant at $95.8 \%$ even when the HMF conversion increased from $21.3 \%$ to $100 \%$. The selectivity toward FFCA was always small and increased slightly from $0.7 \%$ to $1.5 \%$. These results show that DFF selectivity is stable on $\mathrm{Ru} / \mathrm{C}$ in toluene, and thus DFF was obtained in yields as high as $95.8 \%$. Moreover, this excellent DFF yield was obtained at high activity $\left(15.8 \mathrm{~h}^{-1}\right)$, which is much greater than $\sim 3.8 \mathrm{~h}^{-1}$ observed for $\mathrm{Ru}(\mathrm{OH})_{x} / \mathrm{HT}$ catalyst (at $393 \mathrm{~K}$ under flowing oxygen) [14], showing the superiority of $\mathrm{Ru} / \mathrm{C}$ for catalyzing the HMF oxidation to DFF.



Fig. 1. Changes in the activity and selectivity for DFF and FFCA with HMF conversion over $\mathrm{Ru} / \mathrm{C}$ (383 K, $2.0 \mathrm{MPa} \mathrm{O}_{2}, 1.0 \mathrm{mmol} \mathrm{HMF}, 40 \mathrm{mg}$ $\mathrm{Ru} / \mathrm{C}, 10 \mathrm{ml}$ toluene, $0.3-7.0 \mathrm{~h}$ ).
Table 1

Activity and product selectivity in the aerobic oxidation of HMF in toluene on carbon-supported Ru, Pt, Pd, Rh, and Au nanoparticles of comparable size.

\begin{tabular}{|c|c|c|c|c|c|}
\hline \multirow{2}{*}{ Entry } & \multirow{2}{*}{ Catalyst } & \multirow{2}{*}{$\begin{array}{l}\text { Particle size } \\
\text { (nm) }\end{array}$} & \multirow{2}{*}{$\begin{array}{c}\text { Activity } \\
\left(\mathrm{h}^{-1}\right)\end{array}$} & \multicolumn{2}{|c|}{ Selectivity (\%) } \\
\hline & & & & DFF & FFCA \\
\hline 1 & $\mathrm{Ru} / \mathrm{C}$ & $1.7(1.8)^{\mathrm{a}}$ & 61.2 & 96.2 & 0.9 \\
\hline 2 & $\mathrm{Pt} / \mathrm{C}$ & 2.3 & 44.0 & 72.6 & 0.4 \\
\hline 3 & $\mathrm{Pd} / \mathrm{C}$ & 1.7 & 4.9 & 53.1 & 0.6 \\
\hline 4 & $\mathrm{Rh} / \mathrm{C}$ & 1.8 & 5.0 & 40.8 & 0.7 \\
\hline 5 & $\mathrm{Au} / \mathrm{C}$ & 3.5 & 28.2 & 32.5 & 1.0 \\
\hline 6 & $\mathrm{Cb}^{\mathrm{b}}$ & - & $1.1 \%^{\mathrm{c}}$ & 22.1 & 0.4 \\
\hline
\end{tabular}

Reaction conditions: $383 \mathrm{~K}, p\left(\mathrm{O}_{2}\right)=2.0 \mathrm{MPa}, 1.0 \mathrm{mmol} \mathrm{HMF}, 40 \mathrm{mg}$ catalyst (120 mg for $\mathrm{Au} / \mathrm{C}$ ), $10 \mathrm{ml}$ toluene, $\sim 30 \% \mathrm{HMF}$ conversion.

a The number in parenthesis is the $\mathrm{Ru}$ particle size for $\mathrm{Ru} / \mathrm{C}$ after five reaction cycles.

b $0.043 \mathrm{~g}$ of $\mathrm{C}$ was used.

cThe conversion after HMF oxidation for $30 \mathrm{~min}$.

For comparison, several other noble metals, $\mathrm{Pt}, \mathrm{Pd}, \mathrm{Rh}$, and $\mathrm{Au}$, supported on $\mathrm{C}$ were also examined in the HMF oxidation. As shown in Table 1, characterization of these catalysts by TEM shows that the metal particles were 1.8-2.3 $\mathrm{nm}$ in diameter, except for $\mathrm{Au} / \mathrm{C}(3.5 \mathrm{~nm} \mathrm{Au})$, and were similar to the size of $\mathrm{Ru} / \mathrm{C}(1.7 \mathrm{~nm}) . \mathrm{Pt} / \mathrm{C}$ was active for the HMF oxidation, but with a lower activity $\left(44.0 \mathrm{~h}^{-1}\right)$ and DFF selectivity $(72.6 \%)$ than $\mathrm{Ru} / \mathrm{C}\left(61.2 \mathrm{~h}^{-1}\right.$ and $\left.96.2 \%\right)$ at similar HMF conversions ( 30\%) in the kinetic regime. $\mathrm{Au} / \mathrm{C}$ was also active $\left(28.2 \mathrm{~h}^{-1}\right)$, but it gave a DFF selectivity as low as $32.5 \%$. Pd/C and $\mathrm{Rh} / \mathrm{C}$ exhibited very low activities ( 4.9 and $5.0 \mathrm{~h}^{-1}$ ) and DFF selectivities (53.1\% and $40.8 \%$ ) under the same reaction conditions.

The stability and recyclability of $\mathrm{Ru} / \mathrm{C}$ were examined at $383 \mathrm{~K}$ and $2.0 \mathrm{MPa}_{2}$ in the kinetic controlled regime (i.e. at $\sim 30 \%$ HMF conversion). To recycle, the catalyst was simply washed with water. As shown in Fig. 2, the HMF oxidation activity decreased from 61.2 to $53.7 \mathrm{~h}^{-1}$ in the second run, and continuously to $26.0 \mathrm{~h}^{-1}$ in the fifth run, while the DFF selectivity remained almost unchanged. To understand this decline in activity, the filtrate after each run was measured by ICP-AES and showed no detectable leaching of $\mathrm{Ru}$. The oxidation of HMF

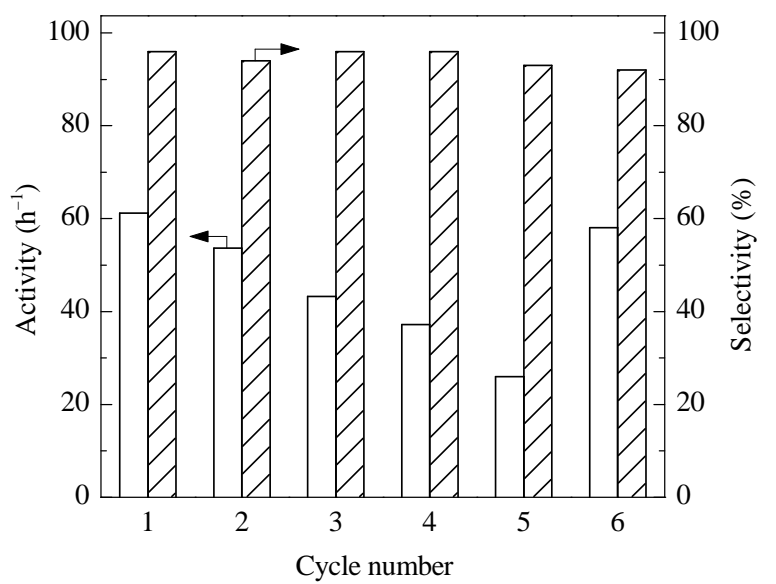

Fig. 2. Activity and DFF selectivity for the recycle examination of HMF oxidation on $\mathrm{Ru} / \mathrm{C}$ at $\sim 30 \% \mathrm{HMF}$ conversion $\left(383 \mathrm{~K}, 2.0 \mathrm{MPa} \mathrm{O}_{2}, 1.0\right.$ mmol HMF, $40 \mathrm{mg} \mathrm{Ru} / \mathrm{C}, 10 \mathrm{ml}$ toluene). $\mathrm{Ru} / \mathrm{C}$ was filtered and simply washed with water for cycles 2-5, and for the 6th cycle it was treated under hydrothermal conditions at $383 \mathrm{~K}$ for $4 \mathrm{~h}$. 
stopped once $\mathrm{Ru} / \mathrm{C}$ was removed from the reaction solution, confirming the heterogeneous nature of the $\mathrm{Ru} / \mathrm{C}$ catalysis. Moreover, TEM images of the used $\mathrm{Ru} / \mathrm{C}$ catalyst demonstrated that the mean diameters of the Ru nanoparticles remained essentially unaltered (1.7 nm vs $1.8 \mathrm{~nm}$, Table 1, entry 1). XPS analysis revealed no significant change in the oxidation state of the $\mathrm{Ru}$ particles after being recycled. Taken together, these results mean the structure of the $\mathrm{Ru} / \mathrm{C}$ catalyst is stable, and thus the observed activity loss during recycling cannot be due to the change in the structure and oxidation state of the $\mathrm{Ru}$ particles or due to being leached out of the catalyst.

Because $\mathrm{Ru} / \mathrm{C}$ is stable, we theorized that the loss in activity may be due to the strong adsorption of the acid byproducts such as FFCA and maleic acid (MA) at the Ru active sites. To verify this, the fresh $\mathrm{Ru} / \mathrm{C}$ catalyst was stirred in the filtered reaction solution at $298 \mathrm{~K}$ before it was examined for a second run, which resulted in similar activity loss $\left(\sim 20 \%, 46.1 \mathrm{~h}^{-1}\right)$. More directly, in a separate reaction, the addition of a small amount of FFCA and MA (2 equivalents of the amount produced at $100 \% \mathrm{HMF}$ conversion) led to a significant decline in the activity $\left(\sim 50 \%, 30.6 \mathrm{~h}^{-1}\right)$. This confirms that the activity loss of $\mathrm{Ru} / \mathrm{C}$ is due to the blockage of the $\mathrm{Ru}$ active sites by the acidic byproducts formed during the HMF oxidation. Accordingly, the catalyst which had been used for five successive cycles was treated under hydrothermal conditions at $383 \mathrm{~K}$ for $4 \mathrm{~h}$ to remove the adsorbed acids, and the activity was almost completely recovered (Fig. 2, cycle 6). This demonstrates the high recyclability of the $\mathrm{Ru} / \mathrm{C}$ catalyst, which is superior to the reported $\mathrm{Ru}(\mathrm{OH})_{x} / \mathrm{HT}$ catalyst that loses $\sim 80 \%$ of its activity in the second cycle at $\sim 50 \%$ DFF yield [14]. Similar activity loss was observed on $\mathrm{RuCl}_{3} / \mathrm{Al}_{2} \mathrm{O}_{3}$, but the activity was harder to recover even after treatment with $\mathrm{NaOH}$ solution [17].

Moreover, HMF can be further oxidized to FFCA and 2,5-furandicarboxylic acid (FDCA) on $\mathrm{Ru} / \mathrm{C}$ by performing the reaction in water instead of toluene in otherwise identical reaction conditions. As shown in Table 2, FFCA and FDCA were obtained with $51.9 \%$ and $8.1 \%$ selectivities, respectively, at $100 \%$ HMF conversion in water. Such changes in the product distribution are due to the facile hydration of aldehyde group to a geminal diol in water, which tends to be further oxidized to acids [22,23]. Addition of hydrotalcite ( $\mathrm{Mg}: \mathrm{Al}=3: 1)$ further improved the yields of FFCA to $82.8 \%$ and FDCA to $75.3 \%$ after the HMF oxidation at $383 \mathrm{~K}$ for $6 \mathrm{~h}$ and at $403 \mathrm{~K}$ for $8 \mathrm{~h}$, respec-
Table 2

Aerobic oxidation of HMF in water on Ru/C.

\begin{tabular}{lcccrcr}
\hline \multirow{2}{*}{ Entry } & \multirow{2}{*}{ Additive $^{2}$} & \multirow{2}{*}{ Time } & Conversion & \multicolumn{3}{c}{ Selectivity (\%) } \\
\cline { 5 - 7 } & & $(\mathrm{h})$ & $(\%)$ & DFF & FFCA & FDCA \\
\hline 1 & - & 7 & 100 & 28.8 & 51.9 & 8.1 \\
2 & hydrotalcite & 6 & 100 & 1.4 & 82.8 & 5.4 \\
$3^{\mathrm{b}}$ & hydrotalcite & 8 & 100 & - & 2.9 & 75.3 \\
\hline
\end{tabular}

Reaction conditions: $383 \mathrm{~K}, 2.0 \mathrm{MPa} \mathrm{O}, 1.0 \mathrm{mmol} \mathrm{HMF}, \mathrm{HMF} / \mathrm{metal}=$ 80 ( $\mathrm{mol} / \mathrm{mol}), 10 \mathrm{ml} \mathrm{H} \mathrm{O}_{2}$.

a 0.2 g hydrotalcite $(\mathrm{Mg} / \mathrm{Al}=3)$.

$\mathrm{b}$ The reaction temperature was $403 \mathrm{~K}$.

tively.

In conclusion, $\mathrm{Ru} / \mathrm{C}$ is an effective and recyclable catalyst for the aerobic oxidation of HMF to DFF, affording DFF in $\sim 96 \%$ yield in toluene. High yields of FFCA and FDCA can also be obtained from $\mathrm{Ru} / \mathrm{C}$ in water in the presence of hydrotalcites. Detailed studies of the structural requirements and reaction mechanism of the HMF oxidation on $\mathrm{Ru} / \mathrm{C}$ are reported elsewhere [24].

\section{References}

[1] Corma A, Iborra S, Velty A. Chem Rev, 2007, 107: 2411

[2] Alonso D M, Bond J Q, Dumesic J A. Green Chem, 2010, 12: 1493

[3] Ståhlberg T, Fu W, Woodley J M, Riisager A. ChemSusChem, 2011, 4: 451

[4] Rosatella A A, Simeonov S P, Frade R F M, Afonso C A M. Green Chem, 2011, 13: 754

[5] Hopkins K T, Wilson W D, Bender B C, McCurdy D R, Hall J E, Tidwell R R, Kumar A, Bajic M, Boykin D W. J Med Chem, 1998, 41: 3872

[6] Del Poeta M, Schell W A, Dykstra C C, Jones S, Tidwell R R, Czarny A, Bajic M, Kumar A, Boykin D, Perfect J R. Antimicrob Agents Chemother, 1998, 42: 2495

[7] Lewkowski J. Arkivoc, 2001, 2:17

[8] Amarasekara A S, Green D, Williams L D. Eur Polym J, 2009, 45: 595

[9] Moreau C, Durand R, Pourcheron C, Tichit D. Stud Surf Sci Catal, 1997, 108: 399

[10] Ma J P, Du Zh T, Xu J, Chu Q H, Pang Y. ChemSusChem, 2011, 4: 51

[11] Carlini C, Patrono P, Galletti A M R, Sbrana G, Zima V. Appl Catal A, 2005, 289: 197

[12] Navarro O C, Canos A C, Chornet S I. Top Catal, 2009, 52: 304

[13] Nie J F, Liu H Ch. Pure Appl Chem, 2012, 84: 765

\section{Graphical Abstract}

Chin. J. Catal., 2013, 34: 871-875 doi: 10.1016/S1872-2067(12)60551-8

\section{Activated carbon-supported ruthenium as an efficient catalyst for selective aerobic oxidation of 5-hydroxymethylfurfural to 2,5-diformylfuran}

NIE Junfang, XIE Jiahan, LIU Haichao* Peking University

$\mathrm{Ru} / \mathrm{C}$ is an effective and recyclable catalyst in the aerobic oxidation of 5-hydroxymethylfurfural (HMF) to 2,5-diformylfuran (DFF), affording a high DFF yield of $95.8 \%$ in toluene.

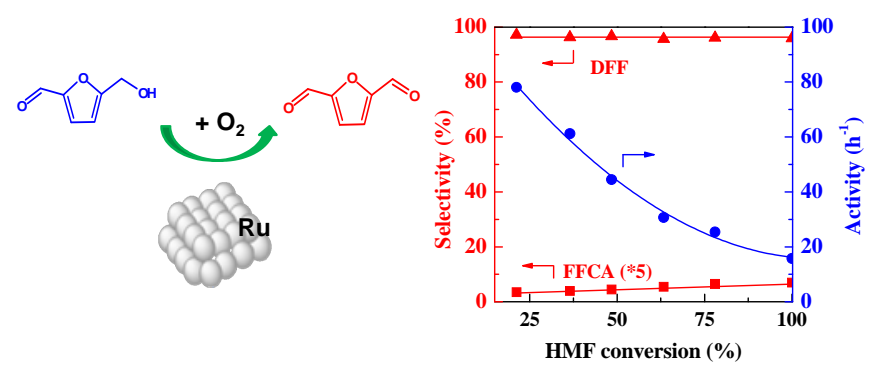


[14] Takagaki A, Takahashi M, Nishimura S, Ebitani K. ACS Catal, 2011, 1: 1562

[15] Yang Zh-Zh, Deng J, Pan T, Guo Q-X, Fu Y. Green Chem, 2012, 14: 2986

[16] Sádaba I, Gorbanev Y Y, Kegnæs S, Putluru S S R, Berg R W, Riisager A. ChemCatChem, 2013, 5: 284

[17] Antonyraj C A, Jeong J, Kim B, Shin S, Kim S, Lee K Y, Cho J K. J Ind Eng Chem, 2013, 19: 1056

[18] Halliday G A, Young R J Jr, Grushin V V. Org Lett, 2003, 5: 2003
[19] Xiang X, He L, Yang Y, Guo B, Tong D M, Hu Ch W. Catal Lett, 2011, 141: 735

[20] Sun J Y, Liu H Ch. Green Chem, 2011, 13: 135

[21] Shen Y H, Zhang Sh H, Li H J, Ren Y, Liu H Ch. Chem-Eur J, 2010, 16: 7368

[22] Vinke P, Van der Poel W, Van Bekkum H. Stud Surf Sci Catal, 1991, 59: 385

[23] Davis S E, Zope B N, Davis R J. Green Chem, 2012, 14: 143

[24] Nie J F, Xie J H, Liu H Ch. J Catal, 2013, 301: 83

\title{
$\mathrm{Ru} / \mathrm{C}$ 催化5-羟甲基糠醛选择氧化高效合成2,5-呋喃二甲醛
}

\author{
聂俊芳, 解佳翰, 刘海超 ${ }^{*}$ \\ 北京大学化学与分子工程学院, 北京分子科学国家实验室, 分子动态与稳态结构国家重点实验室, 北京100871
}

\begin{abstract}
摘要: 在活性炭负载金属钉 $(\mathrm{Ru} / \mathrm{C})$ 催化剂上实现了5-羟甲基棣醛的高效选择氧化. 以甲苯为反应溶剂, 在 $383 \mathrm{~K}$ 和 $2.0 \mathrm{MPa} \mathrm{O}_{2}$ 的反 应条件下, 2,5-呋喃二甲醛(DFF)收率高达 $95.8 \%$. 与活性炭负载的具有相似粒径的Pt, Rh, Pd, Au等其它贵金属催化剂相比, Ru/C 具有更加优良的活性和DFF选择性. 同时Ru/C催化剂结构稳定, 具有良好的重复使用性能. 在相似的反应条件下, 采用水代替甲 苯作为溶剂, 同时添加少量水滑石固体碱, 可便捷地将主要产物从DFF调变为5-甲酰基-2-呋喃甲酸或2,5-呋喃二甲酸, 显示出Ru/C 催化剂在控制5-羊弪甲基糠醛选择氧化反应产物方面的优异性能.
\end{abstract}

关键词: 生物质; 5-羟甲基糠醛; 2,5-呋喃二甲醛; 选择氧化; 钉催化剂

收稿日期: 2013-01-06. 接受日期: 2013-02-18. 出版日期: 2013-05-20.

*通讯联系人. 电话: (010)62754031; 传真: (010)62754031; 电子信箱: hcliu@pku.edu.cn

基金来源：国家自然科学基金(20825310，20973011，21173008); 国家重点基础研究发展计划(973计划, 2011CB808700, 2011CB201400).

本文的英文电子版由Elsevier出版社在ScienceDirect上出版(http://www.sciencedirect.com/science/journal/18722067).

利用生物质代替日益消耗的化石资源有助于实现 油品和化学品的可持续生产 ${ }^{[1,2]}$. 作为一类重要的生物 质基平台分子 ${ }^{[3,4]}$, 5-羟甲基糠醛(HMF) 可以转化生成 2,5-呋喃二甲醛(DFF)等多种重要的化学品. DFF具有多 种用途, 可以用于合成杀菌剂、药品和功能性高分子 等 ${ }^{[5-8]}$.

DFF可以通过选择氧化 HMF 的羟基而制得, 但是 HMF分子中存在活性更高的醛基, 因而通过氧化反应从 HMF高收率地合成DFF具有一定的困难. 因此, 很多均 相和非均相催化剂都被用于这个反应, 试图解决这一问 题 ${ }^{[0 ~ 17]}$. Moreau等 ${ }^{[9]}$ 将 $\mathrm{V}_{2} \mathrm{O}_{5} / \mathrm{TiO}_{2}$ 作为催化剂, $\mathrm{HMF}$ 转化 率和DFF选择性分别可达 $91 \%$ 和 $93 \%$, 但需要较高的催 化剂用量(催化剂/HMF质量比 $=2 / 1$ ), 催化剂活性较低. Xu课题组 ${ }^{[10]}$ 在乙腈溶剂中采用均相的 $\mathrm{VOSO}_{4} / \mathrm{Cu}\left(\mathrm{NO}_{3}\right)_{2}$ 催化剂, 在 $353 \mathrm{~K}$ 下 DFF收率接近 $100 \%$, 但分离不便. Ebitani 课 题组 ${ }^{[14]}$ 使用水滑石 (HT) 担 载的 $\mathrm{Ru}(\mathrm{OH})_{x}\left(\mathrm{Ru}(\mathrm{OH})_{x} / \mathrm{HT}\right)$ 作为催化剂, 在 $N, N-$ 二甲基甲酰 胺(DMF) 溶剂中获得了 $92 \%$ 的DFF收率. Cho课题组 ${ }^{[17]}$ 在 $\mathrm{RuCl}_{3} / \mathrm{Al}_{2} \mathrm{O}_{3}$ 上取得了 $97 \%$ 的DFF收率. 然而, 这些催 化剂在循环使用时活性均明显下降. 最近, 在二甲亚砜 (DMSO) 溶剂中, 以八面体分子篮构型的 $\mathrm{MnO}_{2}$ 作为催化
剂也得到相似的高收率 ${ }^{[15]}$. 但DMSO在氧气气氛下加热 容易歧化,生成有害的 $\mathrm{Me}_{2} \mathrm{SO}_{2}$ 和 $\mathrm{Me}_{2} \mathrm{~S}^{[18,19]}$. 本文以活性 炭负载 $\mathrm{Ru}$ 金属纳米粒子 $(\mathrm{Ru} / \mathrm{C})$ 作为 $\mathrm{HMF}$ 选择氧化的催 化剂, 在甲苯中反应, DFF收率可达 $95.8 \%$, 且催化剂具 有良好的活性和循环使用性能.

采用浸渍法制备 $\mathrm{Ru} / \mathrm{C}$ 催化剂. 将活性炭加入到适 量的 $\mathrm{RuCl}_{3}$ 水溶液中, 振荡并待水分蒸发后置入 $383 \mathrm{~K}$ 烘 箱过夜. 所得固体用 $20 \% \mathrm{H}_{2}-80 \% \mathrm{~N}_{2}$ 混合气在 $623 \mathrm{~K}$ 下 还原 $4 \mathrm{~h}^{[20]}$. 作为对比, 用类似方法制备了 $\mathrm{Pt} / \mathrm{C}, \mathrm{Pd} / \mathrm{C}$ 和 $\mathrm{Rh} / \mathrm{C}$ 催化剂 ${ }^{[20]}$. 这些催化剂的金属担载量均为3\%(质量 分数). $1 \% \mathrm{Au} / \mathrm{C}$ 催化剂采用 $\mathrm{NaBH}_{4}$ 一步还原法制备 ${ }^{[21]}$. $\mathrm{HMF}$ 氧化反应在内置聚四氟乙烯祄管的反应釜 $(50 \mathrm{ml})$ 中进行. 投料量为 $1 \mathrm{mmol} \mathrm{HMF} \mathrm{(98 \% ),} 40 \mathrm{mg}$ 催化剂和 $10 \mathrm{ml}$ 甲苯. 反应产物使用HPLC和UV检测器进行分析, 色谱柱为Alltech OA-1000有机酸柱 ${ }^{[13]}$. 催化剂和HMF 氧化反应溶液中的 $\mathrm{Ru}$ 含量使用电感耦合等离子体原子 发射光谱 (ICP-AES) 进行检测 (Profile Spec, Leeman Labs). 催化剂的X射线光电子能谱(XPS)表征在AXIS Ultra型电子能谱仪(Kratos, Manchester, UK)上进行, 操 作条件为Al靶 $\left(\mathrm{Al} K_{\alpha}, h v=1486.6 \mathrm{eV}\right), 150 \mathrm{~W}$.

图1为在383 $\mathrm{K}$ 和 $2.0 \mathrm{MPa} \mathrm{O}$ 下 $\mathrm{Ru} / \mathrm{C}$ 催化剂的催化活 
性以及DFF和5-甲酰基-2-呋喃甲酸(FFCA)选择性与 HMF转化率之间的关系. 由图可见, 当HMF转化率从 $21.3 \%$ 增至 100\%时, DFF选择性基本稳定在 $95.8 \%$, 而 FFCA选择性仅从 $0.7 \%$ 增至 $1.5 \%$. 这一结果表明, 在甲 苯溶剂中, DFF选择性可以在 $\mathrm{Ru} / \mathrm{C}$ 催化剂存在下保持稳 定, 最终在HMF完全转化时, 其收率可达 $95.8 \%$. 而且, $\mathrm{Ru} / \mathrm{C}$ 催化剂的活性可达 $15.8 \mathrm{~h}^{-1}$, 远高于 $\mathrm{Ru}(\mathrm{OH})_{x} / \mathrm{HT}$ 催 化剂的 $3.8 \mathrm{~h}^{-1}$ (反应条件: $393 \mathrm{~K}, \mathrm{O}_{2}$ 压 $0.1 \mathrm{MPa}$ ) ${ }^{[14]}$.

作为对比, 本文将 $\mathrm{Pt}, \mathrm{Pd}, \mathrm{Rh}$ 和 $\mathrm{Au}$ 担载在活性炭上, 也用于HMF的选择氧化反应中. TEM结果显示(见表1), 除了 $\mathrm{Au} / \mathrm{C}$ 中 Au粒径(3.5 nm)略大外, 其它催化剂的金属 粒子粒径均在1.8 2.3 nm, 与 $\mathrm{Ru} / \mathrm{C}$ 粒径 $(1.7 \mathrm{~nm})$ 接近. 各 催化剂性能的比较在相似的较低HMF转化率( 30\%)下 进行, 以排除浓度差异和扩散的影响. 由表可见, Pt/C也 具有较高的活性 $\left(44.0 \mathrm{~h}^{-1}\right)$ 和DFF选择性(72.6\%), 但分别 低于 $\mathrm{Ru} / \mathrm{C}$ 的 $61.2 \mathrm{~h}^{-1}$ 和 $96.2 \%$. 另外, $\mathrm{Au} / \mathrm{C}$ 的活性为 28.2 $\mathrm{h}^{-1}$, 但DFF选择性仅为 $32.5 \% . \mathrm{Pd} / \mathrm{C}$ 和 $\mathrm{Rh} / \mathrm{C}$ 的活性(4.9和 $5.0 \mathrm{~h}^{-1}$ )和DFF选择性(53.1\%和40.8\%)均较低.

在 $383 \mathrm{~K}$ 和 $\mathrm{O}_{2}$ 压 $2.0 \mathrm{MPa}$ 下, 调节 $\mathrm{HMF}$ 转化率为 $\sim 30 \%$ 的动力学控制区间测试了 Ru/C催化剂的结构稳定 性和循环使用性能. 循环使用前, 回收的 Ru/C采用去离 子水洗涤并真空干燥. 如图2所示, 反应活性在第2次使 用时从 $61.2 \mathrm{~h}^{-1}$ 降至 $53.7 \mathrm{~h}^{-1}$; 至第 5 次时进一步降至 26.0 $\mathrm{h}^{-1}$, DFF选择性则基本保持稳定. 为了考察活性下降的 原因, 我们首先对每次反应后的滤液进行ICP-AES测定, 没有观察到 $\mathrm{Ru}$ 的流失. 将 $\mathrm{Ru} / \mathrm{C}$ 从反应体系中分离出来, 反应即停止进行, 说明 $\mathrm{Ru} / \mathrm{C}$ 在催化反应过程中的多相特 性. TEM结果显示, 反应后的 $\mathrm{Ru} / \mathrm{C}$ 催化剂中 Ru粒径几乎 保持不变(见表1). XPS结果也表明, 反应前后Ru的价态 没有发生明显的改变. 可见, $\mathrm{Ru} / \mathrm{C}$ 催化剂的结构稳定, 循环使用时其活性的降低不是源自 Ru纳米粒子的结构
和价态的改变或者 $\mathrm{Ru}$ 的流失.

我们推测, 催化剂活性的降低可能来自反应的副产 物如FFCA和马来酸(MA)对Ru活性位的强吸附作用. 为 了验证这一想法, 我们将新鲜的 $\mathrm{Ru} / \mathrm{C}$ 催化剂先在室温下 于反应滤液中摚拌, 然后用于HMF反应, 发现了类似的 活性降低(转化率 20\%时活性为 $46.1 \mathrm{~h}^{-1}$ ). 直接加入少 量FFCA和MA (约相当于HMF 100\%转化时各自生成量 的2倍)则导致活性的显著降低( 50\%时 $\left.30.6 \mathrm{~h}^{-1}\right)$. 因此, 循环使用时 $\mathrm{Ru} / \mathrm{C}$ 活性的降低可以归结为反应副产物对 $\mathrm{Ru}$ 活性位的占据. 与此对应, 将循环使用 5 次后的 $\mathrm{Ru} / \mathrm{C}$ 在 $383 \mathrm{~K}$ 下水热处理 $4 \mathrm{~h}$, 即可除去吸附的副产物并使活 性几乎完全恢复(见图2). 这表明 $\mathrm{Ru} / \mathrm{C}$ 具有良好的循环 使用性能. 而文献中报道的 $\mathrm{Ru}(\mathrm{OH})_{x} / \mathrm{HT}$ 催化剂在 $50 \%$ 的 DFF收率下, 第二次循环使用即发生 $80 \%$ 的活性损 失 ${ }^{[14]} ; \mathrm{RuCl}_{3} / \mathrm{Al}_{2} \mathrm{O}_{3}$ 也存在类似的现象 ${ }^{[17]}$, 且催化剂在使 用后即使经过 $\mathrm{NaOH}$ 溶液处理仍无法恢复其活性.

在相同反应条件下将溶剂由甲苯换成水, HMF可被 进一步氧化成FFCA和2,5-呋喃二甲酸(FDCA). 如表2所 示, 在水中当HMF完全转化时, FFCA和FDCA的收率分 别为 $51.9 \%$ 和 $8.1 \%$. 这一产物分布的变化是由于在水中 醛基容易水合生成偕二醇, 并倾向于进一步被氧化成 酸 ${ }^{222,23]}$. 添加固体碱如水滑石 $(\mathrm{Mg} / \mathrm{Al}=3)$ 可以进一步提 高FFCA和FDCA的收率: $383 \mathrm{~K}$ 反应 $6 \mathrm{~h}, \mathrm{FFCA}$ 收率可 达82.8\%; 403 K下反应8 h, FDCA收率可达75.3\%. 由此 可见, 改变反应条件即可很好地调节 Ru/C催化剂上HMF 反应产物的分布, 从而制得所需目标产物.

综上所述, Ru/C 是HMF选择氧化合成DFF有效且可 良好循环使用的催化剂, 在甲苯中DFF收率可达 $95.8 \%$; 当将溶剂换成水并加入水滑石时, 可高收率地得到 FFCA 和FDCA. 关于 $\mathrm{Ru} / \mathrm{C}$ 催化剂结构和HMF氧化反应 机理等方面的研究结果可参看文献[24]. 